\title{
REVIEW
}

\section{The effects of dietary supplementation with Agaricales mushrooms and other medicinal fungi on breast cancer: Evidence-based medicine}

\author{
Maria Rita Carvalho Garbi Novaes, Fabiana Valadares, Mariana Campos Reis, Daniella Rodrigues \\ Gonçalves, Marilia da Cunha Menezes
}

Universidade de Brasília, School of Medicine, Institute of Health Science (ESCS), Brasília/DF, Brazil.

\begin{abstract}
Breast cancer is the most prevalent cancer in women. The most frequent therapeutic approaches for the treatment of this disease are chemotherapy, radiotherapy, hormone therapy, and surgery. Conventional pharmacological treatments cause many harmful side effects in patients. To improve the quality of life of breast cancer patients, researchers have sought alternative adjuvant treatment strategies. To assess the effects of fungi and other basidiomycetes Agaricales on the co-adjuvant treatment of breast cancer, we conducted a literary review of the available scientific evidence. We selected articles published in refereed journals from 1990 to 2011 in Medline, Lilacs, CAPES, Scielo, and Pubmed. Articles written in English, Spanish, and Portuguese were reviewed. We used the following descriptors: Agaricales, medicinal mushroom/fungus, breast cancer, dietary supplementation, synonyms, and related terms. The pharmacological effects of nutritional and medicinal mushrooms have been reported in several experimental clinical studies and have shown promising results in the adjuvant treatment of breast cancer. Adjuvant treatment with mushrooms is associated with improvements in the immunological and hematologic parameters of breast cancer, as well as in the quality of life of these patients. Randomized clinical studies are needed to elucidate the possible mechanisms of action and clinical benefits of these fungi with respect to survival time, disease progression, and metastasis in breast cancer
\end{abstract}

KEYWORDS: Nutritional supplement; Agaricus sylvaticus; Medicinal mushroom; Adjuvant treatment; Basidiomycetes.

Novaes MRCG, Valadares F, Reis MC, Gonçalves DR, Menezes MC. The effects of dietary supplementation with Agaricales mushrooms and other medicinal fungi on breast cancer: Evidence-based medicine. Clinics. 2011;66(12):2133-2139.

Received for publication on May 26, 2011; First review completed on June 26, 2011; Accepted for publication on July 18, 2011

E-mail: ritanovaes@ig.com.br

Tel.: 5561 3254-0925

\section{INTRODUCTION}

Breast cancer is highly prevalent in women. In 2008, the IARC/OMS estimated that breast cancer was the second biggest incidence of cancer in the world (1.29 million cases). In Brazil, it would be responsible for 49,000 new cases in women from 2010 to 2011 and the mortality rate for this type of cancer remains high, on one side, due to the fact that this disease continues to be diagnosed at advanced stages. ${ }^{1,2}$

Treatment for breast cancer is complex and varies according to the histological diagnosis of the patient, the patient's age, the disease stage and the therapeutic approaches taken. ${ }^{3}$

Factors associated with tumor growth and the conventional treatments used to treat cancer often result in malnutrition in breast cancer patients. Side effects caused by conventional treatments, significantly reduced caloric intake and decreased absorption of nutrients can all complicate cancer treatment and reduce the quality of life of cancer patients. ${ }^{4}$

Copyright (c) 2011 CLINICS - This is an Open Access article distributed under the terms of the Creative Commons Attribution Non-Commercial License (http:// creativecommons.org/licenses/by-nc/3.0/) which permits unrestricted noncommercial use, distribution, and reproduction in any medium, provided the original work is properly cited.

No potential conflict of interest was reported.
Previous studies have sought to identify ways to improve the quality of life and nutritional status of cancer patients using adjuvant therapy with mushrooms. ${ }^{4-10}$

The most recent studies have shown that dietary supplementation with Agaricales mushrooms and other medicinal fungi in breast cancer patients can provide benefits, such as antiproliferative and immunomodulatory effects on tumor cells. ${ }^{11-15}$

The aim of this study is to analyze the effects of mushrooms and other basidiomycetous Agaricales as adjuvant treatments in breast cancer.

\section{MATERIALS AND METHODS}

A critical review of articles published in refereed journals between January, 1990 to March, 2011 was performed. Articles were identified in the Medline, Lilacs, Scielo, and Pubmed, Health Science Descriptors (DeCS) and Medical Subject Heading (MeSH) databases by searching for the following terms: in English (Agaricales, Agaricus, medicinal mushroom/fungus, breast cancer, dietary supplementation, edible mushroom effects, lectin), in Portuguese (câncer de mama, cogumelo medicinal), in Spanish (cáncer de mama, suplementación nutricional/dietética, cogumelos, hongos medicinales). 
Table 1 - Mechanisms of action of various modulating substances present in mushrooms.

\begin{tabular}{|c|c|c|c|}
\hline References & Substances & Benefits & Mechanism of Action \\
\hline Wang et al. (1996) & \multirow{5}{*}{ Lectin } & Inhibits the growth of tumor cells & $\begin{array}{c}\text { Two lectins (TML-1 and TML-2) were isolated from the mushroom } \\
\text { Tricholoma mongolicum. Both stimulated the production of } \\
\text { nitrite ions and activated macrophages in mice }\end{array}$ \\
\hline $\begin{array}{l}\text { Novaes et al. (2005a), } \\
\text { Novaes et al. (2005b), } \\
\text { Fortes \& Novaes et al. } \\
(2006){ }^{32} \text { Fortes et al. } \\
(2008){ }^{31} \text { Fortes \& } \\
\text { Novaes }(2011)^{9}\end{array}$ & & $\begin{array}{c}\text { Cytotoxic activity against human tumor cells, } \\
\text { breast cancer and sarcoma } 180 \text { cells, inhibited } \\
\text { proliferation of mastocytoma cells in vitro and } \\
\text { sarcoma } 180 \text { cells in mice }\end{array}$ & $\begin{array}{l}\text { Inhibits cell proliferation by blocking the import of } \\
\text { protein into the nucleus }\end{array}$ \\
\hline Zhang et al. (2009) ${ }^{17}$ & & $\begin{array}{l}\text { Antiproliferative activity toward } \\
\text { hepatoma and breast cancer cells }\end{array}$ & $\begin{array}{c}\text { Showed antiproliferative activity toward hepatoma Hep G2 cells } \\
\text { and breast cancer MCF7 cells with an IC (50) of } 2.1 \mu \mathrm{M} \text { and } \\
\text { approximately } 3.2 \mu \mathrm{M} \text {, respectively }\end{array}$ \\
\hline Yang et al. (2009) ${ }^{18}$ & & $\begin{array}{l}\text { Tumor-suppressing function via apoptosis- } \\
\text { inducing activity in cancer cells }\end{array}$ & $\begin{array}{l}\text { Dimerization of AAL is a prerequisite for tumor cell apoptosis- } \\
\text { inducing activity and requires galactose and glucose as basic } \\
\text { moieties of functional carbohydrate ligands for lectin bioactivity }\end{array}$ \\
\hline Sendra et al. (2010) ${ }^{16}$ & & $\begin{array}{l}\text { Induces an immune response with tumor- } \\
\text { associated glycan specificity and biological } \\
\text { activity similar to that of } A B L\end{array}$ & $\begin{array}{c}\text { Shows high-affinity binding to } \mathrm{T} \text { antigen and reversible } \\
\text { noncytotoxic inhibitory effects on epithelial tumor cell } \\
\text { proliferation }\end{array}$ \\
\hline Fujimiya et al. (1998) & \multirow{7}{*}{$\beta$-Glucan } & Tumoricidal activity & $\begin{array}{l}\text { Directly inhibits tumor cell growth in vitro by inducing apoptotic } \\
\text { processing, increasing expression of the Apo } 2.7 \text { antigen on the } \\
\text { mitochondrial membranes of tumor cells and selective cytotoxicity } \\
\text { toward tumor cells }\end{array}$ \\
\hline Kodama et al. $(2003)^{22}$ & & $\begin{array}{l}\text { Represses cancer progression, hinders } \\
\text { metastatic progress, lessens the expression } \\
\text { of tumor markers and increases NK cell } \\
\text { activity in all patients }\end{array}$ & $\begin{array}{l}\text { Antitumor effect in tumor-bearing mice due to enhancement of } \\
\text { the immune system through the activation of macrophages, T } \\
\text { cells, and natural killer (NK) cells }\end{array}$ \\
\hline $\begin{array}{l}\text { Novaes et al. }(2005 a)^{5}, \\
\quad \text { Novaes et al. (2005b), } \\
\text { Fortes \& Novaes } \\
(2006){ }^{32} \text { Fortes et al. } \\
(2008){ }^{31} \text { Fortes \& } \\
\text { Novaes }(2011)^{9}\end{array}$ & & Enhances the immune system effects & $\begin{array}{l}\text { Increases cellular and humoral immunity, the number and size of } \\
\text { the phagocytic cells, stimulates cytokine production by T cells and } \\
\text { increases the number of NK cells }\end{array}$ \\
\hline Zhang et al. (2006) & & $\begin{array}{l}\text { Dose-dependently reduces proliferation and } \\
\text { viability of MCF-7 breast cancer cells (cancer- } \\
\text { cell growth was decreased by } 50 \% \text { ) }\end{array}$ & $\begin{array}{l}\text { Time-dependently induces cell cycle G1 arrest in approximately } \\
90 \% \text { of the cells by down-regulating the cyclin D1 and cyclin E } \\
\text { expression in MCF-7 breast cancer cells } \\
\text { Induces apoptosis through DNA alterations in subG1 cells } \\
\text { Induces depletion of the anti-apoptotic Bcl-2 protein }\end{array}$ \\
\hline Demir et al. $(2007)^{23}$ & & $\begin{array}{l}\text { Stimulates proliferation and activation of } \\
\text { peripheral blood monocytes in vivo in } \\
\text { patients with advanced breast cancer }\end{array}$ & $\begin{array}{l}\text { Stimulates innate immunity by activating monocytes/ } \\
\text { macrophages (CD95, CD45RA, CD14+) }\end{array}$ \\
\hline Vetvicka et al. (2008) ${ }^{45}$ & & $\begin{array}{l}\text { Inhibits growth of tumor cells in vivo } \\
\text { and affects expression of several important } \\
\text { genes in breast cancer cells }\end{array}$ & $\begin{array}{l}\text { Yeast-derived } \beta \text {-Glucan causes significant stimulation of } \\
\text { phagocytic activity as well as potentiation of synthesis and release } \\
\text { of interleukin (IL)-1, IL-2, IL-4, IL-6, IL-8, IL-13, and tumor necrosis } \\
\text { factor-alpha. }\end{array}$ \\
\hline Jiang et al. (2010) ${ }^{15}$ & & $\begin{array}{l}\text { Inhibits cell proliferation and suppresses the } \\
\text { metastatic behavior of MDA-MB-231 breast } \\
\text { cancer cells }\end{array}$ & $\begin{array}{l}\text { Inhibition of cell proliferation and cell cycle arrest at G2/M phase } \\
\text { in highly invasive MDA-MB-231 human breast cancer cells; linked } \\
\text { to the suppression of secretion of the urokinase plasminogen } \\
\text { activator (uPA) from these cells. } \\
\text { Inhibition of cell adhesion, cell migration and cell invasion }\end{array}$ \\
\hline
\end{tabular}


Table 1 - Cont.

\begin{tabular}{|c|c|c|c|}
\hline References & Substances & Benefits & Mechanism of Action \\
\hline Takaku et al. $(2001)^{28}$ & \multirow{5}{*}{ Ergosterol } & $\begin{array}{l}\text { Direct inhibition of angiogenesis induced } \\
\text { by solid tumors }\end{array}$ & $\begin{array}{c}\text { Tumor growth was retarded by the oral administration of } \\
\text { the lipid fraction extracted from } A \text {. blazei in sarcoma } \\
180 \text {-bearing mice. } \\
\text { Intraperitoneal and subcutaneous administration of ergosterol } \\
\text { inhibited the neovascularization induced by Lewis lung } \\
\text { carcinoma cell-packed chambers and Matrigel, } \\
\text { respectively, in female C57BL/6 mice. }\end{array}$ \\
\hline $\begin{array}{l}\text { Novaes et al. (2005a), } \\
\text { Novaes et al. (2005b), } \\
\text { Fortes \& Novaes } \\
(2006){ }^{32} \text { Fortes et al. } \\
(2008){ }^{31} \text { Fortes \& } \\
\text { Novaes }(2011)^{9}\end{array}$ & & $\begin{array}{l}\text { Inhibition of tumor growth without causing } \\
\text { collateral damage }\end{array}$ & Inhibition of neovascularization induced by tumor growth \\
\hline Wu et al. $(2007)^{26}$ & & Strong antitumor activity & $\begin{array}{c}\text { Decrease of tumor size }(60 \%) \text { by cytotoxicity - exhibits a } \\
\text { significant inhibitory effect on B16-induced melanoma in C57BL/6 } \\
\text { mice. }\end{array}$ \\
\hline Lee et al. $(2009)^{27}$ & & $\begin{array}{l}\text { Strong anti-migratory effect on human } \\
\text { cancer cells }\end{array}$ & $\begin{array}{l}\text { Ergosterol peroxide and daucosterol inhibited the migration of } \\
\text { MDA-MB-231 cells. }\end{array}$ \\
\hline $\begin{array}{l}\text { Thohinung et al. } \\
(2010)^{25}\end{array}$ & & Anti-proliferation effect. & $\begin{array}{l}\text { Cytotoxicity against the human breast cancer and } \\
\text { cholangiocarcinoma cell lines. }\end{array}$ \\
\hline $\begin{array}{l}\text { Novaes et al. (2005a), } \\
\text { Novaes et al. (2005b), } \\
\text { Fortes \& Novaes } \\
(2006))^{32} \text { Fortes et al. } \\
(2008){ }^{31} \text { Fortes \& } \\
\text { Novaes }(2011)^{9}\end{array}$ & \multirow[t]{3}{*}{ Arginine } & $\begin{array}{l}\text { Inhibits tumor growth, reduces nitrogen } \\
\text { losses and contributes to a positive } \\
\text { nitrogen balance }\end{array}$ & $\begin{array}{c}\text { Increases the number of NK cells and T-helper lymphocytes, } \\
\text { stimulates the synthesis of cytokines, promotes the increase of } \\
\text { immunity through the release of growth hormone and produces } \\
\text { nitric oxide, hydroxyproline and polyamines }\end{array}$ \\
\hline Zhang et al. $(2011)^{29}$ & & Anti-proliferation effect & $\begin{array}{c}\text { Depletion of ARGLU1 significantly impairs the growth, as well as } \\
\text { anchorage-dependent and -independent colony formation of } \\
\text { breast cancer cells. }\end{array}$ \\
\hline Tada et al. $(2011)^{30}$ & & Improved anticancer activity & $\begin{array}{l}\text { Mutated arginine on EGFR-lytic peptide produces higher binding } \\
\text { ability to EGFR on cancer cells. }\end{array}$ \\
\hline
\end{tabular}

Articles identified in the indexing databases mentioned above, including both original articles and reviews of the bioactive effects of edible mushrooms on cancer, were selected for inclusion in this study. Experimental trials in animals evaluating the efficacy of medicinal fungi treatments in breast cancer and randomized clinical trials with Agaricales mushrooms (and other medicinal fungi) in humans with breast cancer were also included.

\section{RESULTS AND DISCUSSION}

\section{Bioactive substances found in mushrooms and other Agaricales medicinal fungi}

The therapeutic effects of medicinal mushrooms are due to the presence of lectin, $\beta$-glucan, ergosterol, arginine, and other bioactive substances in mushrooms. ${ }^{5-9}$ The benefits and possible mechanisms of action of these substances are described in Table 1.

Lectins have been shown to be therapeutic agents with anticancer properties in animals and in clinical studies. They cause cytotoxicity and apoptosis and inhibition of tumor growth by preferentially binding to cancer cell membranes. Lectins function by sequestering the body's polyamines, thereby inhibiting cancer cell growth. Lectins also alter the production of many interleukins, activate protein kinases, bind to ribosomes, and inhibit protein synthesis. In addition, lectins modify the cell cycle by inducing cell cycle arrest at the G2/M phase, promoting apoptosis, and stimulating nonapoptotic G1-phase accumulation mechanisms. Finally, lectins can also down-regulate telomerase activity and inhibit angiogenesis. ${ }^{16-20}$

$\beta$-glucan is a glucose polymer present in medicinal mushrooms. It exhibits immunomodulatory effects as well as tumoricidal and antiproliferative activities in cancer patients through the stimulation of natural killer cells, neutrophils, monocytes, macrophages, and T-cells. ${ }^{21-28}$

Ergosterol (or provitamin D2) is a precursor of ergocalciferol, an important substrate in vitamin D biosynthesis and is found in the lipid fraction of Agaricales extracts. This substance has antitumor, antiproliferation, and antimigratory effects on human cancer cells. ${ }^{25-27}$ It has also been shown to inhibit angiogenesis. In a study on sarcoma 180 cells, patients treated with ergosterol demonstrated delayed tumor growth with minimal side effects. For example, the decrease in lymphocyte count that is commonly caused by chemotherapy was not observed in these patients. Ergosterol appears to have no direct in vitro cytotoxic effects on tumor cells, although it inhibits tumor-induced neovascularization. ${ }^{28}$

Arginine is a semi-essential amino acid used as a dietary supplement in cancer patients. It has been associated with a reduction of tumor growth and metastasis progression, and it is reported to have beneficial effects on the immune system, weight gain, and the time of survival of cancer patients. ${ }^{29,30}$

A complete understanding of the actions of these fungi and their bioactive molecules in the prevention and treatment of cancer will require further investigation. However, research shows that many of these substances exert anticarcinogenic, antiviral, antithrombotic, antibiotic, 
Table 2 - The effects of Agaricales mushrooms and other medicinal fungi on breast cancer: experimental studies in animals, in vivo and in vitro.

\begin{tabular}{|c|c|c|c|}
\hline References & Mushroom Species & Target Group/Tumor & Results \\
\hline $\begin{array}{l}\text { Grube et al. } \\
(2001)^{37}\end{array}$ & Agaricus bisporus & Breast cancer cells & $\begin{array}{l}\downarrow \text { aromatase enzyme activity, tumor cell proliferation and } \\
\text { estrogen production }\end{array}$ \\
\hline $\begin{array}{l}\text { Zhao et al. } \\
(2003)^{34}\end{array}$ & & Breast cancer cells (MCF-7) & $\downarrow$ proliferation of tumor cells (via DNase) \\
\hline $\begin{array}{l}\text { Chen et al. } \\
(2006)^{36}\end{array}$ & & $\begin{array}{l}\text { Breast cancer cells (MCF-7) } \\
\text { inoculated in mice }\end{array}$ & $\downarrow$ tumor cell proliferation and tumor growth \\
\hline $\begin{array}{l}\text { Talorete et al. } \\
(2002)^{44}\end{array}$ & Agaricus blazei & $\begin{array}{l}\text { Breast cancer cells } \\
\text { (MCF-7) }\end{array}$ & $\downarrow$ cell proliferation \\
\hline $\begin{array}{l}\text { Takimoto et al. } \\
(2004)^{33}\end{array}$ & & $\begin{array}{l}\text { Naïve } B A L B / c \text { and meth } A- \\
\text { bearing } B A L B / c \text { mice }\end{array}$ & $\begin{array}{l}\uparrow \text { natural killer activity of spleen cells in naïve BALB/C } \\
\text { mice } \\
\text { Potentiated cytotoxic activity in innate and adaptive } \\
\text { immunity in meth A-bearing BALB/c mice }\end{array}$ \\
\hline $\begin{array}{l}\text { Chu et al. } \\
(2002)^{35}\end{array}$ & Coriolus versicolor & $\begin{array}{l}\text { Mice inoculated with } \\
\text { mastocytoma cells and } \\
\text { mammary tumor }\end{array}$ & $\downarrow$ tumor cells growth \\
\hline $\begin{array}{l}\text { Jiang et al. } \\
(2004)^{43}\end{array}$ & Ganoderma lucidum & $\begin{array}{l}\text { Breast cancer cells } \\
\text { (MDA-MB-231) }\end{array}$ & $\begin{array}{c}\downarrow \text { tumor cell proliferation } \\
\text { Inhibited NF-k } \beta \text { messenger activity }\end{array}$ \\
\hline $\begin{array}{l}\text { Thyagarajan et al. } \\
(2007)^{38}\end{array}$ & & $\begin{array}{l}\text { Breast cancer cells } \\
\text { (MDA-MB-231) }\end{array}$ & $\downarrow$ tumor growth and metastasis \\
\hline $\begin{array}{l}\text { Fang et al. } \\
(2006)^{41}\end{array}$ & Lentinus edodes & $\begin{array}{l}\text { Breast carcinoma cells } \\
\text { (MDA-MB-453 and MCF-7) }\end{array}$ & $\uparrow$ antiproliferative activity \\
\hline $\begin{array}{l}\text { Israilides et al. } \\
(2008)^{46}\end{array}$ & & $\begin{array}{l}\text { Breast carcinoma cells } \\
\text { (MCF-7) }\end{array}$ & $\begin{array}{l}\downarrow \text { tumor cell proliferation } \\
\uparrow \text { immune response }\end{array}$ \\
\hline $\begin{array}{l}\text { Sliva et } \mathrm{al} . \\
(2008)^{47}\end{array}$ & Phelinus linteus & $\begin{array}{l}\text { Breast cancer cells } \\
\text { (MDA-MB-231) }\end{array}$ & $\begin{array}{l}\downarrow \text { tumor cell proliferation } \\
\quad \downarrow \text { angiogenesis }\end{array}$ \\
\hline $\begin{array}{l}\text { Jedinak et al. } \\
(2008)^{42}\end{array}$ & Pleurotus ostreatus & $\begin{array}{l}\text { Breast cancer cells } \\
\text { (MCF-7 and MDA-MB-231) }\end{array}$ & Suppressed tumor cell proliferation \\
\hline $\begin{array}{l}\text { Gu \& Leonard } \\
(2006)^{40}\end{array}$ & $\begin{array}{l}\text { Several types of mushrooms } \\
\text { Several types of mushrooms }\end{array}$ & $\begin{array}{c}\text { Breast cancer cells (MCF-7, } \\
\text { MDA-MB-231 and BT-20) }\end{array}$ & Inhibited tumor growth \\
\hline $\begin{array}{l}\text { Petrova et al. } \\
(2007)^{39}\end{array}$ & & $\begin{array}{l}\text { Breast cancer cells } \\
\text { (MCF-7) }\end{array}$ & Inhibited messenger activity of NF-K $\beta$ \\
\hline $\begin{array}{l}\text { Vetvicka et al. } \\
(2008)^{45}\end{array}$ & & Breast cancer cells & $\downarrow$ tumor cell proliferation \\
\hline $\begin{array}{l}\text { Zhao et al. } \\
(2003)^{34}\end{array}$ & Tricholoma mongolicum & Mastocytoma cells (P815) & $\begin{array}{l}\text { Inhibited tumor growth } \\
\text { (via apoptosis-inducing) }\end{array}$ \\
\hline
\end{tabular}

and anti-inflammatory effects in addition to many other activities that provide health benefits. $5,6,9,31-32$

\section{Experimental studies with mushrooms and other Agaricales medicinal fungi}

Promising results have been reported in animals and in vitro using medicinal mushrooms in the treatment of breast cancer and several other cancers. ${ }^{33-49}$ Table 2 provides a summary of the studies mentioned below.

Takimoto et al. $^{33}$ demonstrated that rats administered Agaricus blazei extract orally exhibited increased cytotoxic $\mathrm{T}$ lymphocyte growth, increased levels of interferon-gamma and an increase in NK cells when compared to water-treated controls. This study indicates that mushroom extracts estimulate cytotoxic activity on both, innate and adaptive immunological systems.

Immunomodulatory, antitumor, and antiproliferative effects of lectin isolated from various types of Agaricaceae mushrooms have been demonstrated by Zhao et al. ${ }^{34}$ The lectin contained in Agaricus bisporus has been shown to exhibit an antiproliferative effect on breast cancer cells, and the lectin contained in Tricholoma mongolicum has been shown to have an inhibitory effect on mastocytoma cells (P815) in vitro.

In an in vivo study, extracts of Coriolus versicolor promoted significant tumor reductions in mice inoculated with mastocytoma tumor cells and mammary tumors. ${ }^{35}$

Chen et al. ${ }^{36}$ examined the ability of an Agaricus bisporus extract to inhibit aromatase at the estrogen receptor in vitro in MCF-7 cells and rat ovarian cells and in vivo in rats. The extract inhibited cell proliferation. The linoleic and linolenic acid present in the extract inhibited aromatase activity by altering or mutating the active sites. The in vivo study showed that the extract decreased proliferation and tumor growth without affecting apoptosis in rats.

In studies of breast cancer cells (MFC-7), Grube et al. ${ }^{37}$ showed that Agaricus bisporus extract suppresses the activity of aromatase, resulting in a reduction of estrogen production, which is a major contributor to postmenopausal breast cancer in women.

In experiments with breast cancer cells (MDA-MB-231), Thyagarajan et al. ${ }^{38}$ showed that Ganoderma lucidum extract inhibits cell proliferation and the formation of new cell 
Table 3 - The results of clinical studies using Agaricales and other medicinal fungi for dietary supplementation and adjuvant treatment in patients with breast cancer.

\begin{tabular}{|c|c|c|c|c|}
\hline References & Mushroom Species & Active Principle & Target Group & Results \\
\hline Dolby $(1997)^{12}$ & Grifola frondosa & $\begin{array}{l}\text { D-fraction- } \beta \text {-Glucan and } \\
\text { total mushroom }\end{array}$ & $\begin{array}{l}15 \text { women with breast } \\
\text { cancer }\end{array}$ & $\begin{array}{c}\downarrow \text { tumor size } \\
\text { improvement in clinical and biochemical } \\
\text { parameters } \\
\downarrow \text { of vomiting and anorexia }\end{array}$ \\
\hline Kodama et al. (2002) ${ }^{13}$ & Grifola frondosa & Mushroom powder & $\begin{array}{l}\text { Liver, lung and breast } \\
\text { cancer patients }\end{array}$ & $\begin{array}{c}\text { increasing immune-competent cell activity } \\
\text { cancer regression or significant symptom } \\
\text { improvement }\end{array}$ \\
\hline Gennari et al. (2002) ${ }^{48}$ & Agaricus sylvaticus & Mushroom Capsule & $\begin{array}{c}1 \text { patient with breast } \\
\text { cancer and lung metastasis }\end{array}$ & $\begin{array}{l}\uparrow \text { the number of NK cells and CD } 56 \\
\text { total remission of lung metastasis }\end{array}$ \\
\hline $\begin{array}{l}\text { See et al. } \\
(2002)^{49}\end{array}$ & Agaricus blazei & Mushroom tea & $\begin{array}{l}5 \text { stage VI breast cancer } \\
\text { patients }\end{array}$ & $\begin{array}{l}\uparrow \text { the number of NK cells } \\
\text { stimulate macrophages and other } \\
\text { immunomodulatory effects }\end{array}$ \\
\hline $\begin{array}{l}\text { Hong et al. } \\
(2008)^{7}\end{array}$ & $\begin{array}{l}\text { Several types of } \\
\text { mushroom }\end{array}$ & Mushroom total & $\begin{array}{l}362 \text { women with breast } \\
\text { cancer in menopause }\end{array}$ & $\begin{array}{l}\text { the consumption of dietary mushrooms may } \\
\text { decrease breast cancer risk in postmenopausal } \\
\text { women }\end{array}$ \\
\hline $\begin{array}{l}\text { Shin et al. } \\
(2010)^{14}\end{array}$ & $\begin{array}{l}\text { Several types of } \\
\text { mushroom }\end{array}$ & Mushroom total & $\begin{array}{l}358 \text { women with breast } \\
\text { cancer }\end{array}$ & $\begin{array}{l}\uparrow \text { mushroom consumption } \downarrow \text { risk of breast } \\
\text { cancer in premenopausal women (stronger } \\
\text { with hormone receptor positive tumors) }\end{array}$ \\
\hline
\end{tabular}

colonies through the negative regulation of the expression of c-myc, an oncogene. The combination of G. lucidum extract with green tea extract demonstrated a synergistic effect by suppressing secretion of urokinase plasminogen, which is a breast cancer cell activator, and thereby suppressed the growth and invasion of metastatic breast cancers.

In a study of breast cancer cells (MCF7), Petrova et al. ${ }^{39}$ noted that extracts of fungi significantly inhibited the reporter activity of nuclear factor-kappa $\beta(\mathrm{NF}-\kappa \beta)$ by interfering negatively in its activation pathway. The study was conducted with 28 fungi extracts, $40 \%$ of which were found to inhibit NF- $\kappa \beta$ activity.

$\mathrm{Gu} \&$ Leonard $^{40}$ reported the activities of 38 species of edible mushrooms in estrogen receptor-positive (MCF-7) and negative (MDA-MB-231, BT-20) human breast cancer cells. In aqueous extracts from Coprinellus sp., Flammulina velutipes, and Coprinus comatus, anticancer agents were identified that actively inhibited tumor growth.

Fang et al $^{41}$ conducted an in vitro investigation of fractions of ethyl acetate extracts from Shiitake mushrooms (Lentinus edodes) via biological assays of apoptosis and cell cycle analysis in two human breast carcinoma cell lines (MDA-MB-453 and MCF-7). The authors observed antiproliferative activity in all strains. Apoptosis was induced in $50 \%$ of the tumor cell lines via the positive regulation of bax, a pro-apoptotic protein. Cell cycle analysis revealed a decrease in the percentage of cells in S phase, an induction of cdk inhibitors and p21 and a suppression of CDK4 and cyclin D1 activities, thus indicating cell cycle arrest.

Studies using MCF-7 and MDA-MB-231 cells evaluated the effectiveness of various types of edible mushroom extracts. Jedinak \& Sliva, ${ }^{42}$ using flow cytometry, revealed that Pleorotus ostreatus inhibited the proliferation of these cells in breast and colon cancers via p53-dependent and p53independent mechanisms. This fungus exerted its effect by inducing the expression of the tumor suppressor p53 and the cyclin-dependent kinase inhibitor p21 (CIP1/WAF1), but at the same time inhibited the phosphorylation of retinoblastoma protein $(\mathrm{Rb})$ in MCF-7 and HT-29 cells, breast and colon cells respectively. ${ }^{42}$
A study by Jiang et al. ${ }^{43}$ revealed that Ganoderma lucidum inhibits proliferation of MDA-MB-231 breast cancer cells. By inhibiting Akt and NF-kappa $\beta$ activity in MDA-MB-231 cells, Ganoderma lucidum reduced their growth.

Talorete et al. ${ }^{44}$ isolated breast cancer cells (MCF-7) and exposed them to an aqueous extract of Agaricus blazei. The results indicated that this extract was able to reduce cell proliferation in $26 \%$ compared to the control group, by significantly enhancing the expression of an API gene regulatory complex in the human breast cancer cell line MCF7. This, again, highlights the anticarcinogenic potential of mushrooms.

In a study of rats inoculated with breast cancer cells, Vetvicka et al. ${ }^{45}$ observed a reduction in cell proliferation after oral supplementation of $\beta$-Glucan extracted from medicinal mushrooms. Likewise, a decrease in the proliferation of cancer cells has been reported in studies carried out by Israilides et al. ${ }^{46}$ with breast cancer cells (MCF-7) and by Sliva et al. ${ }^{47}$ using the MDA-MB-231 cell line.

\section{Clinical studies with breast cancer patients using Agaricales mushrooms and other medicinal fungi}

Although there are some inconsistencies in the results of clinical studies regarding the use of medicinal mushrooms as an adjuvant therapy in breast cancer treatment, the majority of studies suggest a beneficial effect (Table 3).

A study in patients with breast cancer who received four daily doses (1.6 g each) of Agaricus sylvaticus revealed that Agaricus sylvaticus supplementation resulted in an increased number of natural killer (NK) cells in $75.7 \%$ of the patients. More than half of the patients were receiving chemotherapy or radiotherapy, which typically reduces the numbers of NK cells in the body. ${ }^{45,11}$

In a clinical study of various cancers, including breast cancer (stage IV), Sliva et al. ${ }^{47}$ provided patients with a complex of immunomodulatory components, including Agaricus blazei tea (10 mg/day). After six months of treatment, some patients had increased NK cell activity, as well as increased levels of TNF- $\alpha$ (tumor necrosis factor), 
erythrocytes, hemoglobin, and glutathione. In contrast, the number of $\mathrm{TNF}-\alpha$ receptors was reduced. Diarrhea and occasional nausea were reported, but the quality of life had improved. The combination of immune-active components was effective in increasing NK cell function and other immunological parameters in patients with advanced stages of cancer, thus providing an effective nutritional combination for the treatment of the late stages of cancer. ${ }^{47}$

Gennari et al. $^{48}$ reported a case study of a patient with breast cancer and showed that dietary supplementation with Agaricus sylvaticus increased the number of CD56+ NK cells in the blood and caused a total regression of lung metastasis.

Dolby ${ }^{12}$ reported that the D-fraction o $\beta$-D-Glucan (extracted from Maitake) and mushroom tablets of Grifola frondosa had a positive effect on the health status of the 15 breast cancer patients included in the study. This study reported an improvement in the clinical parameters and laboratory test results of patients as well as improvements in their hematological parameters, reductions in the amount of vomiting caused by chemotherapy, increased appetite and reduced anorexia, which can be a side effect of conventional treatments.

Hong et al. ${ }^{7}$ conducted a study with 362 breast cancer patients between 30 and 65 years of age. The frequency of ingestion of mushrooms was measured through a specific questionnaire. It was found that both the daily intake and the frequency of consumption were inversely related to the risk of breast cancer, especially in postmenopausal women. Similar results were reported by Shin et al. ${ }^{14}$; however, in the Shin study, the consumption of medicinal mushrooms showed a strong protective effect against breast cancer in premenopausal women as well.

Several published experimental clinical studies have reported that medicinal mushrooms exhibit beneficial effects on the health and quality of life in breast cancer patients. The use of supplements as adjunctive therapies for the treatment of breast cancer has shown promising results, such as antiproliferative effects on tumor cells and immunomodulatory activities in the body. However, few articles have examined the effects of supplementation with medicinal mushrooms for the treatment of breast cancer. Therefore, new protocols for the purpose of conducting clinical trials are required to elucidate the possible mechanisms of action and clinical benefits of these fungi with respect to the survival time, clinical progression and quality of life of breast cancer patients.

\section{ACKNOWLEDGMENTS}

Financial Support: This review is part of a research project that was supported by the scholarship Scientific Iniciation Project - PIC from the Institute of Health Science - FEPECS.

\section{AUTHOR CONTRIBUTIONS}

Novaes MRCG participated at the heading, analysis and preparation of the manuscript, obtained a scholarship from the Scientific Iniciation Project of the Institute of Health Science - PIC/FEPECS. Valadares F, Reis MC, Gonçalves DR and Menezes MC were responsible for the collection and analysis of data and production of the final scientific work.

\section{REFERENCES}

1. Brazil. Ministry of Health Ministry of National Health Care National Cancer Institute [INCA]. Estimates October 20: incidence of cancer in Brazil. Rio de Janeiro, INCA, Brazil in 2009.

2. Guerra MR, Gallo CVM, Mendonça GAS. Risk of cancer in Brazil: trends and recent epidemiological studies. Rev Cancer. Brazil. 2005;51:227-34.
3. Brito C, Portela MC, Vasconcellos MTL. SUS oncological care to women with breast cancer in Rio de Janeiro. Rev Public Health. 2005;39:874-81.

4. Shang EC, Weiss S, Kaehler G. The Influence of Early Supplementation of Parenteral Nutrition on Quality of Life and Body Composition in Patients with Advanced Cancer. JPEN J Parenter Enteral Nutr. 2006;30:222-30, doi: 10.1177/0148607106030003222.

5. Novaes MRCG, Fortes RC. Antitumor effects of edible Agaricaceae mushrooms. Rev Nutr Bras. 2005;4:207-17.

6. Novaes MRCG, Novaes LCG. Drug-nutrient in edible mushrooms and other basidiomycetous Agaricales. Rev Bras Nutr Clin. 2005;20:181-7.

7. Hong SA, Kim K, Nam SJ, Kong G, Kim MK. A case-control study on the dietary intake of mushrooms and breast cancer risk among Korean women. Int J Cancer. 2008;122:919-23, doi: 10.1002/ijc.23134.

8. Ahn WS, Kim DJ, Chae GT, Lee JM, Bae SM, Sin JI, et al. Natural killer cell activity and quality of life were improved by consumption of a mushroom extract, Agaricus blazei Murill Kyowa, in gynecological cancer patients undergoing chemotherapy. Int J Gynecol Cancer. 2004;14:589-94, doi: 10.1111/j.1048-891X.2004.14403.x.

9. Fortes RC, Novaes MRCG. The effects of Agaricus sylvaticus fungi dietary supplementation on the metabolism and blood pressure of patients with colorectal cancer during post surgical phase. Nutr Hosp. 2011;26:176-86.

10. Costa JV, Novaes MRCG, Asquieri ER. Chemical and antioxidant potential of Agaricus sylvaticus mushroom grown in Brazil. J Bioanal Biomed. 2011;3:049-054.

11. Gennari J, Gennari M, Fellipe JR. O Agaricus sylvaticus aumenta o número de células natural killer em pacientes com câncer. Revista de Medicina Complementar. 2001;7:42-9.

12. Dolby V. An extract from maitake mushroom is an important anticancer. Better Nutr. 1997;59:38-59.

13. Kodama N, Komuta K, Nanba H. Can maitake MD-fraction aid cancer patients? Altern Med Rev. 2002;7:236-9.

14. Shin A, Kim J, Lim SY, Kim G, Song MK, Lee ES, et al. Dietary mushroom intake and risk of breast cancer based on hormone receptor states. Nutr Cancer. 2010;62:476-83, doi: 10.1080/01635580903441212.

15. Jiang J, Sliva D. Novel medicinal mushroom blend suppresses growth and invasiveness of human breast cancer cells. Int J Oncol. 2010;37:152936, doi: 10.3892/ijo_00000689.

16. Sendra VG, Zlocowski N, Nores GA, Irazoqui FJ. Anti-idiotypic antibody mimicking a T-antigen-specific lectin inhibits human epithelial tumor cell proliferation. Immunol Cell Biol. 2010;88:787-94, doi: 10.1038/icb. 2010.49.

17. Zhang GQ, Sun J, Wang HX, Ng TB. A novel lectin with antiproliferative activity from the medicinal mushroom Pholiota adiposa. Acta Biochim Pol. 2009;56:415-21.

18. Yang N, Li DF, Feng L, Xiang Y, Liu W, Sun H, et al. Structural basis for the tumor cell apoptosis-inducing activity of an antitumor lectin from the edible mushroom Agrocybe aegerita. J Mol Biol. 2009;387:694-705, doi: 10.1016/j.jmb.2009.02.002.

19. De Mejía EG, Prisecaru VI. Lectins as bioactive plant proteins: a potential in cancer treatment. Crit Rev Food Sci Nutr. 2005;45:425-45, doi: 10.1080/ 10408390591034445.

20. Wang HX, Liu WK, Ng TB, Ooi VE, Chang ST. The immunomodulatory and antitumor activities of lectins from the mushroom Tricholoma mongolicum. Immunopharmacology. 1996;31:205-11, doi: 10.1016/01623109(95)00049-6.

21. Fujimiya Y, Suzuki Y, Oshiman K, Kobori H, Moriguchi K, Nakashima $\mathrm{H}$, et al. Selective tumoricidal effect of soluble proteoglucan extracted from the basidiomycete, Agaricus blazei Murill, mediated via natural killer cell activation and apoptosis. Cancer Immunol Immunother. 1998;46:147-59, doi: 10.1007/s002620050473.

22. Kodama N, Komuta K, Nanba H. Effect of Maitake (Grifola frondosa) DFraction on the activation of NK cells in cancer patients. J Med Food. 2003;6:371-7, doi: 10.1089/109662003772519949.

23. Demir G, Klein HO, Mandel-Molinas N, Tuzuner N. Beta glucan induces proliferation and activation of monocytes in peripheral blood of patients with advanced breast cancer. Int Immunopharmacol. 2007;7:113-6, doi: 10.1016/j.intimp.2006.08.011.

24. Zhang M, Chiu LC, Cheung PC, Ooi VE. Growth-inhibitory effects of a beta-glucan from the mycelium of Poria cocos on human breast carcinoma MCF-7 cells: cell-cycle arrest and apoptosis induction. Oncol Rep. 2006;15:637-43.

25. Thohinung S, Kanokmedhakul S, Kanokmedhakul K, Kukongviriyapan V, Tusskorn O, Soytong K. Cytotoxic 10-(indol-3-yl)-[13]cytochalasans from the fungus Chaetomium elatum ChE01. Arch Pharm Res. 2010;33:1135-41, doi: 10.1007/s12272-010-0801-5.

26. Wu JY, Zhang QX, Leung PH. Inhibitory effects of ethyl acetate extract of Cordyceps sinensis mycelium on various cancer cells in culture and B16 melanoma in C57BL/6 mice. Phytomedicine. 2007;14:43-9, doi: 10.1016/j. phymed.2005.11.005.

27. Lee DY, Lee SJ, Kwak HY, Jung L, Heo J, Hong S, et al. Sterols isolated from Nuruk (Rhizopus oryzae KSD-815) inhibit the migration of cancer cells. J Microbiol Biotechnol. 2009;19:1328-32. 
28. Takaku T, Kimura Y, Okuda H. Isolation of an Antitumor Compound from Agaricus blazei Murill and Its Mechanism of Action. J. Nutr. 2001;131:1409-13.

29. Zhang D, Jiang $P, X u Q$, Zhang X. Arginine and Glutamate-rich 1 (ARGLU1) Interacts with Mediator Subunit 1 (MED1) and Is Required for Estrogen Receptor-mediated Gene Transcription and Breast Cancer Cell Growth. J Biol Chem. 2011;286:17746-54, doi: 10.1074/jbc.M110. 206029.

30. Tada N, Horibe T, Haramoto M, Ohara K, Kohno M, Kawakami K. A single replacement of histidine to arginine in EGFR-lytic hybrid peptide demonstrates the improved anticancer activity. Biochem Biophys Res Commun. 2011;407:383-8, doi: 10.1016/j.bbrc.2011.03.030.

31. Fortes RC, Melo AL, Recôva VL, Novaes MRCG. Alterações lipídicas em pacientes com câncer colorretal em fase pós-operatória: ensaio clínico randomizado e duplo-cego com fungos Agaricus sylvaticus. Rev bras. colo-proctol. 2008;28:281-8.

32. Fortes RC, Novaes MRCG. Effects of dietary supplementation with Agaricales mushrooms and other fungi in medicinal therapy against cancer. Revista Brasileira de Cancerologia. 2006;52:363-71.

33. Takimoto H, Wakita D, Kawaguchi K, Kumazawa Y. Potentiation of cytotoxic activity in naïve and tumor-bearing mice by oral administration of hot-water extracts from Agaricus brazei fruiting bodies. Biol Pharm Bull. 2004;27:404-6, doi: 10.1248/bpb.27.404.

34. Zhao C, Sun H, Tong X, Qi Y. An antitumour lectin from the edible mushroom Agrocybe aegerita. Biochem J. 2003;374:321-7, doi: 10.1042/ BJ20030300.

35. Chu KK, Ho SS, Chow AH. Coriolus versicolor: a medicinal mushroom with promising immunotherapeutic values. J Clin Pharmacol. 2002;42:976-84.

36. Chen S, Oh SR, Phung S, Hur G, Ye JJ, Kwok SL, et al. Anti-aromatase activity of phytochemicals in white button mushrooms (Agaricus bisporus). Cancer Res. 2006;66:12026-34, doi: 10.1158/0008-5472.CAN-06-2206.

37. Grube BJ, Eng ET, Kao YC, Kwon A, Chen S. White button mushroom phytochemicals inhibit aromatase activity and breast cancer cell proliferation. Journal of Nutrition. 2001;131:3288-93.

38. Thyagarajan A, Zhu J, Sliva D. Combined effect of green tea and Ganoderma lucidum on invasive behavior of breast cancer cells. Int J Oncol. 2007;30:963-9.
39. Petrova RD, Mahajna J, Reznick AZ, Wasser SP, Denchev CM, Nevo E. Fungal substantiate modulators of NF-kappaB activation pathway. Mol Biol Rep. 2007;34:145-54, doi: 10.1007/s11033-006-9027-5.

40. Gu YH, Leonard J. In vitro effects on proliferation, apoptosis and colony inhibition in ER-dependent and ER-independent human breast cancer cells by selected mushroom species. Oncol Rep. 2006;15:417-23.

41. Fang N, Li Q, Yu S, Zhang J, He L, Ronis MJ, et al. Inhibition of growth and induction of apoptosis in human cancer cell lines by an ethyl acetate fraction from shiitake mushrooms. J Altern Complement Med. 2006;12:125-32, doi: 10.1089/acm.2006.12.125.

42. Jedinak A, Sliva D. Pleorotus ostreatus inhibits proliferation of human breast cancer and colon cancer cells through p53-dependent as well as p53-independent pathway. Int J Oncol. 2008;33:1307-13.

43. Jiang J, Slívova V, Harvey K. Valachovicova T, Sliva D. Ganoderma lucidum suppresses growth of breast cancer cells though the inhibition of Akt/NF- Kappa $\beta$ signaling. Nutr Cancer. 2004;49:209-16, doi: 10. 1207/s15327914nc4902_13.

44. Talorete TP, Isoda H, Maekawa T. Agaricus blazei (class Basidiomycotina) aqueous extract enhances the expression of c-Jun protein in MCF-7 cells. J Agric Food Chem. 2002;50:5162-6, doi: 10.1021/jf011566p.

45. Vetvicka V, Vashisht A, Saraswat-Ohri S, Vetvickova J. Immunological effects of yeast and mushroom derived beta-glucans. J Med Food. 2008;11:615-22, doi: 10.1089/jmf.2007.0588

46. Israilides C, Klets D, Arapoglou D, Philippousis A, Pratsinis H, Ebringeróva A, et al. In vitro cytostatic and immunomodulatory properties of the medicinal mushroom Lentinus edodes. Phytomedicine. 2008;15:512-9, doi: 10.1016/j.phymed.2007.11.029.

47. Sliva D, Jedinak A, Kawasaki J, Harvey K, Shirov V. Phellinus linteus suppresses growth, angiogenesis and invasive behaviour of breast cancer cells through the inhibition of AKT signalling. Br J Cancer. 2008;98:134856, doi: $10.1038 /$ sj.bjc. 6604319 .

48. Gennari JL, Veronesi R, Gennari MS. Edible mushroom Agaricus sylvaticus used as therapeutics complement in a patient with breast cancer and lung metastasis. Rev Bras Med. 2002;59:537-8.

49. See D, Mason S, Roshan R. Increased tumor necrosis factor alpha (TNFalpha) and natural killer cell (NK) function using an integrative approach in late stage cancers. Immunol Invest. 2002;31:137-53, doi: 10. 1081/IMM-120004804. 